\title{
A Lawyer's Perspective on Canadian Refugee Policy
}

by Michael Schelew

The comments below reflect my own experiences in Metropolitan Toronto and may or may not coincide with the experiences of other lawyers in Toronto or the rest of Canada. Though some observations arise from my former position as a refugee co-ordinator for the Canadian Section (Anglophone) of Amnesty International, any opinions expressed in this article are personal to me and may or may not be the official position of Amnesty International.

There have been many important administrative changes in the inlandrefugee determination procedure over the past few years. For the most part, these changes have made life easier for the refugee claimant going through the inland process. As a lawyer representing refugee claimants in Canada, my major concerns are that the internalrefugee determination procedure be fair, and that the process not create undue hardship for the refugee claimant and his/her family.

With respect to fairness, inland claimants are permitted to be represented by counsel in dealings with the Department of Immigration. However, this right of representation does not extend to the port of entry. Even if counsel happens to be present at the port of entry, counsel is not permitted to attend the interview. A claimant's right to counsel should be effective immediately upon indication of his/her intention to seek refugee status and the claimant should be so informed.

Some claimants arrive at ports of entry other than Metropolitan Toronto and wish to have their claims heard in Metropolitan Toronto because that is where their family resides or a support system exists. I am not aware of any policy or guidelines which facilitate a refugee's claim being held at an Immigration Centre nearest to the person's intended destination, if requested.

In addition to rights to counsel and the facility to hold a hearing near support systems for the claimant, justice delay- ed is frustrating as well as unjust. I remember the time, not so long ago, when a person claiming refugee status at the Pearson International Airport could have an inquiry within one week. Now, refugees have to wait six to seven months. Furthermore, as has happened to me on several occasions upon my arriving at an Immigration Centre for a long-awaited inquiry, I was told that, due to scheduling problems, the inquiry had to be rescheduled to a later date which inevitably meant another lengthy period of waiting.

With regard to claims for refugee status that have been made after claimants have entered the country as tourists and are consequently in-status, I have had to wait more than six months at Toronto Central for an inquiry. Another difficulty with in-status claims is that such claimants do not have the right to work or appeal. These two rights are extremely important and 1 believe legislative amendments are necessary to guarantee them.

\section{Right to Work}

During the waiting period for an inquiry, a refugee claimant cannot obtain a work permit. If a person arrives in Toronto with no family or other support system to assist him or her, or if a person or family arrives in Toronto and their family or relatives residing in Toronto do not have sufficient resources to provide adequate financial support, then the claimant and his/her family are in serious difficulty. Furthermore, in Ontario, welfare is not available to refugee claimants until they have made a claim at an inquiry. (Of course, the Department has no jurisdiction over welfare.) Thus, there is no safety net for claimants until they have had their inquiry. After I explained to one immigration official the difficult financial circumstances of a claimant and his family who were waiting for an inquiry, he telephoned me a day later with an inquiry date arranged; there had been a cancellation. Departmental officials should be commended for their understanding in such situations.

Another problem that refugee families face when they arrive in Canada is education for their children. Although this is not within the jurisdiction of the Immigration Department, it would be helpful if a consistent policy were formulated regarding the schooling of the children of refugee claimants.

Once the day for the claimant's inquiry has arrived, the claimant can officially claim refugee status and request an employment authorization. The Department has instituted a new procedure whereby a pre-employment letter is given to a claimant if immediate need can be shown. This is an excellent administrative practice because the refugee claimant can obtain an employment authorization as soon as a job offer becomes available.

Immigration officials are very co-oper-

(Continued on p. 12) 
Lawyer's Perspective

(continued from p. 11)

ative regarding work permits after an inquiry. Often, a claimant has come to an inquiry with an offer of employment, and the Immigration official representing the Department at the inquiry has arranged to have the person interviewed immediately after the inquiry in order to obtain a work permit.

Nevertheless, there are often misunderstandings regarding the criteria for granting a work permit. I recently attended an expedited interview regarding a claimant's request for a work permit, given the serious financial situation of the refugee and his family. The interviewing officer recognized the need but was about to deny the permit because the claimant had been here for only three weeks and was already applying for a work permit. When I reminded the official that we were dealing with a bona fide refugee claimant, it was agreed that an employment authorization should be issued. The issue is not whether the claimant was bona fide, nor is it the time it took for the claimant to arrive at such an interview. The criterion for issuing a work permit is, simply, need.

Based upon my experience, there appears to be a general attitude among Departmental officials that once an employment authorization has been given to a male refugee claimant, it is unreasonable to expect that his wife should also be granted a work permit. Proving need so that the other spouse can obtain an employment authorization is extremely difficult.

\section{Examination under Oath}

At the inquiry, a refugee claim is made. Then the inquiry is adjourned for an "Examination under Oath" to take place at a future date. It is at this Examination that the claimant has the opportunity to make the claim. The delay between an inquiry and an "Examination under Oath" is increasing: a few years ago, one could obtain a date for the Examination within a week or two of the inquiry. Now, waiting two to three months is not uncommon.

There has been an improvement over the years in the professionalism of the Senior Immigration Officers (S.I.O.'s) that preside at "Examinations under
Oath". Although there is no consistency regarding the procedure on these occasions, I have always been allowed to develop the claim of the refugee with the S.I.O. clarifying various parts of the claim after I have finished my questioning. S.I.O.'s are very co-operative and try to ensure that claimants have the best opportunity to present their claims. Occasionally, an S.I.O.'s attempt to clarify certain points verges on cross-examination. Though this is not the function of the presiding official at an "Examination under Oath", I also recognize that the line between clarification and cross-examination is a fine one.

Two disappointing aspects of the "Examination under Oath" are 1) the quality of the interpreters, and 2) the delay in receiving the transcript from the Examination. Recently, I actually had to adjourn an "Examination under Oath" because the interpreter was doing such an incompetent job. At other times, I have been on the verge of adjourning but continued because I believed the Examination could be saved by written submissions. (Since I speak Spanish, and in fact represent many claimants using that language, I can judge the accuracy of a translation.) A correct translation is essential to a fair hearing. The Department should pay what is necessary to attract competent interpreters and establish guidelines regarding the hiring of such interpreters.

Although I am generally satisfied with the quality of the transcripts, I am disappointed with the delay in receiving them. In the past, it would take approximately four weeks to receive a transcript, compared to the current threeor four-month delay after the "Examination under Oath".

\section{R.S.A.C.}

Once a copy of the transcript has been received, I usually prepare written submissions that are sent to the Refugee Status Advisory Committee (R.S.A.C.) in Ottawa, which reviews the transcripts with my submissions and makes the final decision. I have noticed a great deal of improvement in the R.S.A.C.'s decision-making. It is no secret that I have been disappointed in the past with the quality of the decisions emanating from the Committee. I had very little confidence in the R.S.A.C.'s ability to identify accurately a bona fide claimant. Important administrative changes, however, have resulted in more accurate decisions. I now have a degree of confidence in the R.S.A.C.'s ability to recognize a legitimate claimant. Furthermore, the R.S.A.C. is extremely co-operative in situations where a refugee claimant receives relief from a nongovernmental organization or from private individuals. When I have brought this state of affairs to the R.S.A.C.'s attention, the Registrar has always expedited the case.

Another welcome development on the part of the Committee is its new policy of forwarding prejudicial information about a claimant who has no knowledge of such information. The claimant is now given an opportunity to respond. In two recent cases, I received notice from the Committee of the existence of prejudicial information unknown to the claimant, with the request that the "Examination under Oath" be reopened to give the claimant an opportunity to respond.

My most serious concern about the R.S.A.C. is its ability to make adverse findings of credibility on the basis of written material alone. If a claim is not manifestly unfounded, the R.S.A.C. should not be making a credibility assessment without being able to witness the demeanour of the claimant.

A response to this concern has been the establishment of pilot projects in Montreal and Toronto, where a member of the Committee is present when the claimant is giving testimony. At such hearings, a credibility assessment is made and forwarded to the Committee. This pilot project is most welcome as a temporary or interim measure. However, until an oral hearing before those who will decide whether or not a claimant is a Convention refugee becomes an integral part of the inland-refugee determination procedure, this serious procedural deficiency could result in a miscarriage of justice with alarming consequences for the refugee claimant.

Another concern I have with the R.S.A.C. is the delay it takes between 
the time the transcript arrives in Ottawa and the time the decision is made. Its internal procedures should be streamlined.

\section{Special Review Committee}

If the R.S.A.C. is of the opinion that the claimant is not a refugee, the matter is referred to a Special Review Committee to ascertain if there are sufficient humanitarian and compassionate grounds for allowing the claimant to remain in Canada. I am disappointed with the Special Review Committee. I have referred cases to it, cases which I believed, on a cautious and conservative interpretation of the Committee's guidelines, fell within its mandate, only to be disappointed with a negative decision. I believe a review of the Special Review Committee is necessary.

\section{Immigration Appeal Board}

The treatment of refugee cases by the Immigration Appeal Board (I.A.B.) is not free from difficulty. The I.A.B. must decide, on the basis of written materials, whether a claim, if allowed to proceed to an oral hearing, would be successful.

Like the R.S.A.C., the Board is placed in a position where it must make adverse findings of credibility on the basis of written materials only. For reasons previously stated, I believe that this practice is procedurally unfair. The Board is preoccupied with the question of credibility, and rightly so. Often, refugee claimants will lie in order to obtain a tourist visa in a Canadian embassy, which will allow them to come to Canada and claim refugee status. Some claimants will lie at a Canadian port of entry in order to enter for the purpose of finding a trusted source of reliable information about how best to make a claim for refugee status.

In my opinion, such a course of conduct is consistent with the refugee's well-founded fear of persecution. I believe that this type of misrepresentation ought not to be relied upon as a basis for rejecting a claim for lack of credibility.

The I.A.B., at oral hearings, attaches too much weight to evidence from our officials abroad who have been requested by a representative of the Department to verify a claimant's story. I have been involved with two cases where officials of the Department have telexed offices abroad to interview witnesses whom the claimants mentioned. In each case, the witnesses denied knowing the refugee claimant in question. Such denial makes perfect sense in that the witness abroad is probably concerned about his or her own security and would worry about saying anything for fear of getting the claimant "in trouble" in Canada or elsewhere. It is unfair to accept as evidence these unsigned telexes from abroad and to give them any serious evidentiary weight. It is extremely difficult for counsel to come up with an adequate explanation if no one can be crossexamined on the contents of the telex. These examples indicate that perhaps the Immigration Appeal Board is not as sensitive as it could be with respect to the reliability of such evidence.

With regard to delays, the Board is behaving in an exemplary fashion. Its response to applications for redetermination is well within a reasonable time period. The scheduling of oral hearings can take up to six months.

\section{Federal Court Appeals}

Although a claimant can appeal a decision to the Federal Court of Canada, I believe that this is not the answer. The Federal Court has very narrow grounds for review and is not the appropriate forum for correcting miscarriages of justice.

\section{Appeals to the Office of the Minister of Employment and Immigration}

I do not hesitate to appeal to the Office of the Minister of Employment and Immigration if I believe that a breakdown in the inland-refugee determination procedure has occurred, resulting in a miscarriage of justice. The Minister's Office has consistently dealt with my appeals in a serious and thorough manner. The willingness of the Minister's Office to perform this function is deeply appreciated; it constitutes a crucial safety valve in an inland-refugee determination procedure that may break down from time to time by incorrectly rejecting a legitimate refugee claimant who, if returned home, could be exposed to a dangerous situation.

\section{Delays in Family Reunification}

Those claimants who wish to bring their family members to Canada to join them after the claimants have been accepted face serious delays. This is indeed tragic, given that they have already been separated from their families for a lengthy period of time. Many families cannot survive these delays; family breakdowns often occur. I do not know how many times I have had to encourage the Immigration Centre, where the claim had been made, to transfer the file to an inland office, whereupon I had to encourage the inland office to contact the embassy in the country where the family was located to begin the processing of the family to Canada. The Department says that family reunification is given priority. However, family-class and designated-class applications are also given priority. When everything is given priority, then nothing really has priority.

\section{Problem of Non-Bona Fide Claims}

I have consistently mentioned the delays that take place at every stage of the procedure. These delays are created, in part, because there are many claimants who are not bona fide. They abuse the inland process by making refugee claims in order to remain in Canada for a long period of time. These abusive claims have created a backlog and affect bona fide claimants. Making a refugee claim can be an extremely stressful experience. Long delays mean that a refugee claimant may suffer long periods of stress or anxiety.

Abusive claims have caused sympathetic and co-operative Immigration officials to become cynical and indifferent. I am extremely frustrated that the Department has not established procedures that can quickly identify abusers and remove them from the procedure as quickly as possible. (I say this with

(Continued on p. 14) 
trepidation because $I$ am fearful that the Department may over-react by implementing procedures that will lead to the removal, not only of abusers, but also of legitimate claimants.) When dealing with abusive claims, the Department must ensure that the interests of legitimate refugee claimants are not adversely affected.

\section{Unethical Lawyers and Immigration Consultants}

I am equally frustrated with unethical lawyers and immigration consultants who knowingly take an abusive claim just to earn a fee. These lawyers and immigration consultants are highly irresponsible and they threaten the integrity of our inland-refugee determination procedure.

\section{Overseas Refugee Determination Procedure}

With regard to Canada's overseasrefugee determination procedure, I am not satisfied at all that Canadian embassy officials have the necessary training to identify accurately a bona fide refugee claimant. Furthermore, a refugee claimant in an embassy does not have the same procedural safeguards as a claimant in Canada.

I recently became involved with a Yugoslav dissident from Germany who made a claim in our embassy in Bonn. The person was denied the opportunity of presenting medical evidence that was fundamental to his claim. Furthermore, his wife was not provided with an interpreter even though she requested one, given her unfamiliarity with English. The claim was bona fide but denied. The dissident arrived in Canada and made a claim for refugee status. His claim was recently accepted by the Refugee Status Advisory Committee. The case illustrates the inadequacies of refugee determinations abroad.

\section{Visa Requirements on Refugee- Producing Countries}

Visa requirements often block an important escape route to Canada which may be the most logical and accessible country of refuge for the claimant. The Department must realize that Canada is primarily a country of resettlement, but to a lesser and limited extent, it is also a country of first asylum. After all, that is why we have an elaborate inland-refugee determination procedure.

With respect to the imposition of visa requirements on refugee-producing countries, if persons from a country in question were significantly abusing Canadian immigration procedures, visa requirements would of course be necessary. However, in the absence of any significant immigration abuse, it is contrary to Canada's humanitarian tradition to impose a visa requirement on a refugee-producing country. I can only conclude that if a visa requirement is so imposed, the Department does not want to accept any refugees from that country. I realize that Canada cannot accept all the world's refugees. But if the numbers from a particular country are manageable, why not?

The recent imposition of a visa requirement on Guatemala is a good case in point. There is no significant immigration abuse from Guatemala (to my knowledge, ) and the number of Guatemalan refugee claimants in Canada is relatively small. People who engage in legitimate dissent in Guatemala are often tortured and executed. Canada is a logical and accessible country of refuge for Guatemalan claimants. It is mean-spirited to impose a visa requirement on Guatemala; the visa requirement prevents Guatemalans whose lives are in danger from escaping their government tormentors and attaining peace and security in Canada.

\section{$\bullet \bullet \bullet$}

I have attempted to highlight some of my own concerns as a lawyer representing refugee claimants. The last thing I would want to do is to give the impression that the inland-refugee determination procedure is all wrong. On the contrary, there is a lot right about our procedure. As Canadians, we should be proud of our Senior Immigration Officers when they show flexibility on procedural matters in order to soften the impact of administrative procedures on the claimants. We can also be proud of their professionalism in conducting "Examinations under Oath". We can be proud of the R.S.A.C. Its decision- making is more accurate. It is prepared to expedite claims for just cause, and it has instituted a pilot project on oral hearings in Montreal and Toronto.

One of our major challenges, however, is to eliminate the abuse from our system, because this abuse affects bona fide claimants. Another challenge is to eliminate the delays that have adverse psychological affects on bona fide refugee claimants and also attract abusers. The solution to these two serious problems is to institute an oral hearing for all claimants at an early stage in the procedure, which will not only identify bona fide refugee claimants but also abusers. We must not forget the relief needs of claimants. It is the responsibility of the federal government to ensure that a claimant and his or her family can survive during the time it takes to make a claim.

I have attempted to identify certain areas that create hardships for refugees. Delays in the procedure are very stressful for claimants. Their difficulty in obtaining work permits is not conducive to their successful integration and establishment in Canadian society. The lack of an adequate relief program leaves refugee claimants particularly vulnerable if they are unable to find work. The lack of a co-ordinated policy between the federal government and the provinces over areas of jurisdiction affecting the lives of refugee claimants is also a concern. The fact that refugee claimants must flee to Canada and claim refuge for what would be considered legitimate dissent in Canada is tragic. It is also tragic when their problems are compounded by administrative procedures in Canada that are not sensitive to their needs.

The Department of Immigration must look at the inland-refugee determination procedure as a humanitarian problem and not one of enforcement. It must ensure that the procedure is fair and not unduly harsh on refugee claimants. After all, by definition, bona fide refugee claimants have suffered enough.

\section{$\bullet \bullet$}

Michael Schelew is a Toronto lawyer with the firm of Heifetz, Crozier and Schelew. 